\title{
Bifidobacterium stercoris sp. nov., isolated from human faeces
}

\author{
Min-Soo Kim, Seong Woon Roh and Jin-Woo Bae \\ Department of Life and Nanopharmaceutical Sciences and Department of Biology, Kyung Hee \\ University, Seoul 130-701, Republic of Korea
}

Correspondence

Jin-Woo Bae

baejw@khu.ac.kr
Bifidobacteria are non-motile, non-sporulating, obligately anaerobic, non-gas-producing, saccharoclastic bacteria that belong to the family Bifidobacteriaceae in the class Actinobacteria, which comprises Gram-positive bacteria that have DNA with a high $\mathrm{G}+\mathrm{C}$ content (Ventura et al., 2007). As bifidobacteria facilitate the fermentation of a large variety of oligosaccharides, they are one of the most well-known probiotic bacteria and are considered the main target organism for inclusion in prebiotic foods, which may provide health benefits (Gibson \& Roberfroid, 1995; Saulnier et al., 2009; Ventura et al., 2007). However, despite the physiological importance of bifidobacteria in the intestine, according to culture-independent studies (especially metagenomic studies based on the analysis of genomic DNA and rRNA gene libraries), they comprise only a small part of the diverse bacterial population found

\section{Abbreviation: F6PPK, fructose-6-phosphate phosphoketolase.}

The GenBank/EMBL/DDBJ accession numbers for the 16S rRNA gene and $h s p 60$ sequences of strain $\mathrm{Eg} 1^{\top}$ are FJ611793 and FJ770059, respectively.

A neighbour-joining phylogenetic tree based on partial hsp60 sequences is available as supplementary material with the online version of this paper. in the intestinal microbiota; however, the exact population in the human intestine has not been fully established (Eckburg et al., 2005; Palmer et al., 2007; Turroni et al., 2009; Wang et al., 2005). The general characteristics of the genus Bifidobacterium are the presence of fructose-6phosphate phosphoketolase (F6PPK) and production of both acetic and lactic acids from glucose fermentation in a molar ratio of $3: 2$ (Scardovi, 1986). To date, 30 species and nine subspecies have been described as belonging to the genus Bifidobacterium.

The bifidobacterial strain $\mathrm{Eg}^{\mathrm{T}}$ was isolated from faeces of a healthy, 27-year-old Korean male on Eggerth-Gagnon agar supplemented with $5 \%$ horse blood at $37{ }^{\circ} \mathrm{C}$ for 2 days in an anaerobic chamber (Bactron II; Sheldon Manufacturing) containing $\mathrm{N}_{2} / \mathrm{H}_{2} / \mathrm{CO}_{2}(90: 5: 5)$. Strain $\mathrm{Eg}^{\mathrm{T}}$ was subcultured on Bifidobacterium medium (BM; DSMZ medium 58) under anaerobic conditions and stored as a suspension in $10 \%$ skimmed milk (BBL) containing $10 \%$ glycerol at $-80{ }^{\circ} \mathrm{C}$.

Bifidobacterium adolescentis KCTC $3216^{\mathrm{T}}$ and Bifidobacterium ruminantium KCTC $3425^{\mathrm{T}}$ were obtained from the Korean Collection for Type Cultures as reference strains. All experiments were performed using bacterial 
Table 1. Comparison of phenotypic characteristics of strain $\mathrm{Eg} 1^{\top}$ and its closest phylogenetic neighbours

Strains: 1, Bifidobacterium stercoris sp. nov. $\mathrm{Eg}^{\mathrm{T}} ; 2$, B. adolescentis KCTC $3216^{\mathrm{T}}$; 3, B. ruminantium KCTC $3425^{\mathrm{T}}$. Data were obtained in this study unless indicated. All strains were anaerobic and Gramstain-positive, fermented glucose with production of acetic and lactic acids in a molar ratio of $3: 2$ and produced F6PPK (Biavati \& Mattarelli, 1991; Gavini et al., 1991; Scardovi, 1986) and were positive for production of acid from D-glucose, maltose, raffinose and salicin and production of acid phosphatase, leucine arylamidase, naphtholAS-BI-phosphohydrolase, arginine arylamidase and proline arylamidase. All strains were negative for catalase, urease, gelatin hydrolysis, nitrate reduction, indole formation, D-mannose fermentation and production of alkaline phosphatase, esterase (C4), esterase lipase (C8), lipase (C14), trypsin, $\alpha$-chymotrypsin, $\alpha$-fucosidase, $N$-acetyl- $\beta$ glucosaminidase, $\beta$-glucuronidase, $\alpha$-mannosidase, arginine dihydrolase, $\beta$-galactosidase-6-phosphate, glutamic acid decarboxylase, alanine arylamidase, cystine arylamidase, glutamyl glutamic acid arylamidase, leucyl glycine arylamidase, pyroglutamic acid arylamidase and valine arylamidase.

\begin{tabular}{|c|c|c|c|}
\hline Characteristic & 1 & 2 & 3 \\
\hline Aesculin hydrolysis & + & + & - \\
\hline \multicolumn{4}{|l|}{ Acid production from: } \\
\hline L-Arabinose & + & + & - \\
\hline Cellobiose & + & - & - \\
\hline D-Fructose & - & - & + \\
\hline D-Galactose & - & + & + \\
\hline Lactose & + & + & - \\
\hline Melibiose & + & - & + \\
\hline D-Ribose & + & - & + \\
\hline Sucrose & - & - & + \\
\hline Trehalose & + & - & - \\
\hline Turanose & + & - & - \\
\hline D-Xylose & + & + & - \\
\hline D-Mannitol & + & + & - \\
\hline D-Sorbitol & - & + & - \\
\hline Methyl $\alpha$-D-glucoside & + & - & - \\
\hline Amygdalin & + & + & - \\
\hline Arbutin & - & + & + \\
\hline Glycogen & + & - & + \\
\hline Starch & + & - & + \\
\hline \multicolumn{4}{|l|}{ API Rapid ID 32A results } \\
\hline$\alpha$-Arabinosidase & - & + & - \\
\hline$\alpha$-Galactosidase & + & + & - \\
\hline$\beta$-Galactosidase & + & + & - \\
\hline$\alpha$-Glucosidase & + & + & - \\
\hline$\beta$-Glucosidase & + & + & - \\
\hline Glycine arylamidase & + & + & - \\
\hline Histidine arylamidase & + & + & - \\
\hline Leucine arylamidase & + & + & - \\
\hline Phenylalanine arylamidase & + & - & - \\
\hline Serine arylamidase & + & - & - \\
\hline Tyrosine arylamidase & + & - & - \\
\hline \multicolumn{4}{|l|}{ API ZYM results } \\
\hline$\alpha$-Galactosidase & + & + & - \\
\hline$\beta$-Galactosidase & + & + & - \\
\hline$\alpha$-Glucosidase & + & + & - \\
\hline
\end{tabular}

Table 1. cont.

\begin{tabular}{|cccc|}
\hline Characteristic & $\mathbf{1}$ & $\mathbf{2}$ & $\mathbf{3}$ \\
\hline$\beta$-Glucosidase & + & + & - \\
DNA G + C content $(\mathrm{mol} \%)^{*}$ & 57.8 & $59.0^{a}$ & $57.0^{b}$ \\
\hline
\end{tabular}

${ }^{\star}$ Data obtained from: $a$, GenomesOnline (http://www.genomesonline. org/); b, Biavati \& Mattarelli (1991).

strains cultivated and maintained in $\mathrm{BM}$ at $\mathrm{pH} 6.8$ and $37{ }^{\circ} \mathrm{C}$ for 2 or 3 days unless stated otherwise. Gram staining was performed using a Gram-staining kit (bioMérieux). Spore staining was performed using malachite green dye. Phase-contrast microscopy (Nikon) was used to observe the morphology of individual cells as well as Gram and spore staining. To determine bile resistance, strain $\mathrm{Eg} 1^{\mathrm{T}}$ was cultivated in PYG medium (DSMZ medium 104) supplemented with $0.05,0.1,0.15,0.2,0.3$, $0.4,0.5,1.0$ and $1.5 \%(\mathrm{w} / \mathrm{v})$ bile salts (Sigma). Catalase and oxidase activities were determined using $3 \%(\mathrm{v} / \mathrm{v})$ hydrogen peroxide and $1 \%(\mathrm{w} / \mathrm{v})$ p-tetramethylphenylenediamine solutions (bioMérieux), respectively. The motility of strain $\mathrm{Eg}^{\mathrm{T}}$ was determined by stabbing into PYG medium containing $0.4 \%$ agar. Indole production and nitrate reduction were tested using indole nitrite medium (BBL). To investigate enzyme activities and acid production from various carbohydrates, API 50CHL, API 20A, API ZYM and Rapid ID 32A (bioMérieux) were used according to the manufacturer's instructions. F6PPK activity of strain $\mathrm{Eg} 1^{\mathrm{T}}$ was determined using a phosphoketolase assay (Orban \& Patterson, 2000; Scardovi, 1986). The end products of glucose fermentation in cells cultured in Lactobacillus MRS broth (BBL) at $37{ }^{\circ} \mathrm{C}$ for 4 days were analysed by HPLC using an LC-10AT liquid chromatograph and an SPD-10A VP detector (Shimadzu) with an Alltech Prevail organic acid column (Grace Davison Discovery Sciences). The fermentation products were acetic acid and lactic acid in a molar ratio of $1.76: 1$, which closely corresponded to the usual molar ratio of $3: 2$ for acetic and lactic acid production by Bifidobacterium species (Scardovi, 1986). Other results of the phenotypic characterization are given in Table 1 and the species description.

To measure DNA-DNA relatedness and $\mathrm{G}+\mathrm{C}$ content, genomic DNA was extracted from strain $\mathrm{Eg}^{\mathrm{T}}$ and the two reference strains using a G-spin Genomic DNA extraction kit (iNtRON Biotechnology). DNA-DNA relatedness was determined using the fluorometric method described by Ezaki et al. (1989) with some modifications (Hirayama et al., 1996). Strain $\mathrm{Eg}^{\mathrm{T}}$ showed $41 \%$ DNA-DNA relatedness to $B$. adolescentis KCTC $3216^{\mathrm{T}}$ and $17 \%$ DNA-DNA relatedness to B. ruminantium KCTC $3425^{\mathrm{T}}$. As reported by Wayne et al. (1987), a bacterial species should include strains with $>70 \%$ DNA-DNA relatedness, so the results of this study suggested that strain $\mathrm{Eg} 1^{\mathrm{T}}$ was a member of a novel species of the genus Bifidobacterium. The $\mathrm{G}+\mathrm{C}$ 
content of strain $\mathrm{Eg} 1^{\mathrm{T}}$ was determined using a fluorimetric method using SYBR Green I and real-time PCR (Gonzalez \& Saiz-Jimenez, 2002). Genomic DNA from Escherichia coli $\mathrm{K}-12$ and the reference strains was used for calibration (Gonzalez \& Saiz-Jimenez, 2002). The G $+C$ content of strain $\mathrm{Eg} 1^{\mathrm{T}}$ was estimated to be $57.8 \mathrm{~mol} \%$, which is consistent with the high $\mathrm{G}+\mathrm{C}$ content (55-67 mol\%) found in the family Bifidobacteriaceae (Jian et al., 2001).

The 16S rRNA gene sequence of strain $\mathrm{Eg} 1^{\mathrm{T}}$ was amplified by colony PCR with four bacteria-specific primers $(8 \mathrm{~F}$, 968F, 518R and 1492R; Baker et al., 2003). The amplification products were purified using a QIAquick PCR Purification kit (Qiagen) and sequenced using a BigDye Terminator cycle sequencing ready reaction kit (Applied Biosystems), according to the manufacturers' instructions. The reaction mixtures were analysed using an automated DNA analyser system (PRISM 3730XL DNA Analyzer; Applied Biosystems) and the 16S rRNA gene sequence fragments were assembled using SeqMan software (DNASTAR). The nearly full-length $16 \mathrm{~S}$ rRNA gene sequence obtained from strain $\mathrm{Eg}^{\mathrm{T}}$ was compared with other sequences in the GenBank database. Strain $\mathrm{Eg} 1^{\mathrm{T}}$ was related to members of the genus Bifidobacterium in the phylum Actinobacteria and exhibited highest 16S rRNA gene sequence similarity to $B$. adolescentis YIT $4011^{\mathrm{T}}$ and $B$. ruminantium JCM $8222^{\mathrm{T}}$ (98.36 and $97.93 \%$, respectively). A total of 38 nearly full-length $16 \mathrm{~S}$ rRNA gene sequences from reference strains were aligned with that of strain $\mathrm{Eg} 1^{\mathrm{T}}$ using the multiple sequence alignment program CLUSTAL $\mathrm{X}$ version 1.83 (Thompson et al., 1997) and the alignment was trimmed and converted to MEGA format for phylogenetic analysis. Phylogenetic consensus trees using neighbourjoining (Saitou \& Nei, 1987) and maximum-parsimony (Kluge \& Farris, 1969) algorithms were constructed and visualized using MEGA4 (Tamura et al., 2007) and tested by randomly selecting 1000 bootstrap replicates. Phylogenetic consensus trees were visualized with MEGA4 (Tamura et al., 2007). Phylogenetic analysis of 16 S rRNA gene sequences showed that strain $\mathrm{Eg} 1^{\mathrm{T}}$ fell within the bifidobacteria cluster and was most closely related to B. adolescentis YIT $4011^{\mathrm{T}}$ and B. ruminantium JCM $8222^{\mathrm{T}}$ (Fig. 1).

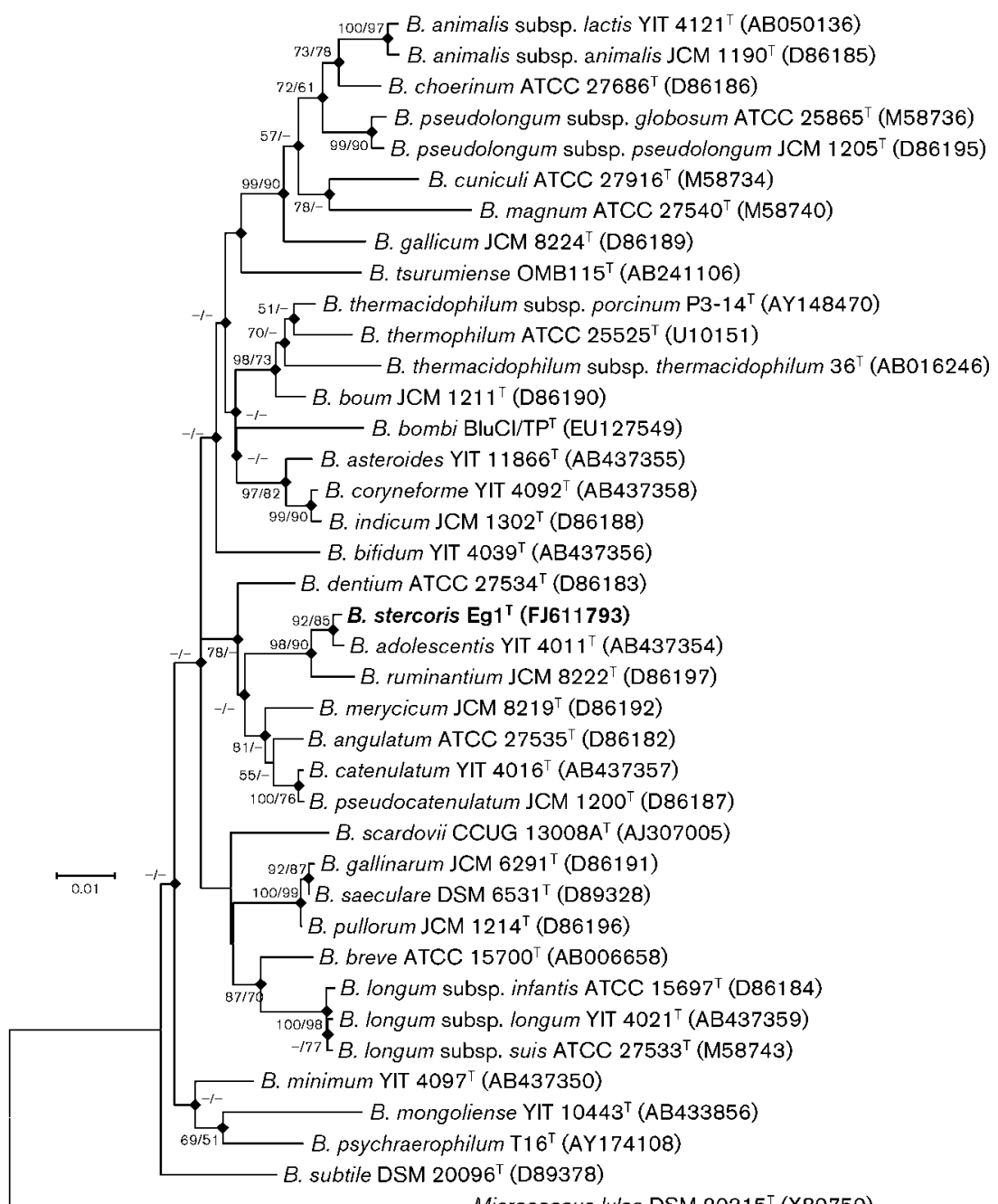

Micrococcus Iylae DSM 20315 (X80750)
Fig. 1. Neighbour-joining phylogenetic consensus tree based on 16S rRNA gene sequences showing the phylogenetic position of strain $\mathrm{Eg} 1^{\top}$ in the genus Bifidobacterium. Filled diamonds indicate that the corresponding nodes were also recovered in the tree generated using the maximum-parsimony algorithm. Bootstrap values $(>50 \%)$ based on 1000 replicates for the neighbour-joining/maximumparsimony methods are shown at branch nodes; -, bootstrap support $\leqslant 50 \%$. Bar, 1 substitution per 100 nucleotide positions. 
A housekeeping gene ( $h s p 60$, encoding the $60 \mathrm{kDa}$ heatshock protein) was used as an additional phylogenetic marker to identify bifidobacterial species (Jian et al., 2001; Zhu et al., 2003). The partial hsp60 sequence of strain $\mathrm{Eg}^{\mathrm{T}}{ }^{\mathrm{T}}$ was obtained and analysed in a similar way to that for the $16 \mathrm{~S}$ rRNA gene sequence, using the primers and method described by Okamoto et al. (2008) and the neighbourjoining algorithm. A 616-bp fragment of the $h s p 60$ sequence was obtained and analysed with 31 hsp60 sequences from type strains of species of the genus Bifidobacterium (Supplementary Fig. S1, available in IJSEM Online). The hsp60 sequence of strain $\mathrm{Eg}^{\mathrm{T}}{ }^{\mathrm{T}}$ showed $99.35 \%$ sequence similarity to that of $B$. adolescentis JCM $1275^{\mathrm{T}}$, which indicated relatedness at the species level (96.5-100\%), and $92.13 \%$ sequence similarity to that of $B$. ruminantium JCM $8222^{\mathrm{T}}$, indicating interspecies relatedness (80-96\%; Jian et al., 2001; Zhu et al., 2003). Even though analysis of the $h s p 60$ sequence is a more accurate tool for the identification of species of the genus Bifidobacterium than 16S rRNA gene sequence analysis, the low DNA-DNA relatedness $(41 \%)$ between strain Eg1 ${ }^{\mathrm{T}}$ and $B$. adolescentis KCTC $3216^{\mathrm{T}}$ confirmed that these two strains belonged to different species.

On the basis of our phenotypic, genotypic and phylogenetic studies, we propose that strain $\mathrm{Eg} 1^{\mathrm{T}}$ is included in the genus Bifidobacterium as a member of a novel species, Bifidobacterium stercoris sp. nov.

\section{Description of Bifidobacterium stercoris sp. nov.}

Bifidobacterium stercoris (ster'co.ris. L. gen. n. stercoris of dung, excrement, ordure).

Anaerobic, Gram-stain-positive, non-motile and nonspore-forming. Cells are club-like or branch-shaped, 4.0$6.0 \mu \mathrm{m}$ long and $1.0 \mu \mathrm{m}$ wide, and are generally observed as single cells. Colonies on $\mathrm{BM}$ agar at $37^{\circ} \mathrm{C}$ after 2 days are $1.0-1.5 \mathrm{~mm}$ in diameter, white and circular with a glistening surface, an umbonate side view and a mucoid texture. The optimal temperature for growth is $37^{\circ} \mathrm{C}$. Cells survive 0.05 and $0.1 \%$ bile salts, but not $0.15 \%$ bile salts. Oxidase- and catalase-negative. F6PPK activity is present. The end products of glucose fermentation are acetic acid and lactic acid in a molar ratio of 1.76:1 (about $3: 2$ ). Indole formation and nitrate reduction are negative. With API 20A, aesculin hydrolysis is positive, but gelatin hydrolysis and urease activity are negative. With API 50CHL, aesculin hydrolysis is positive and acid is produced from amygdalin, L-arabinose, cellobiose, D-glucose, methyl $\alpha$-D-glucoside, glycogen, lactose, maltose, D-mannitol, melibiose, raffinose, D-ribose, salicin, starch, trehalose, turanose and D-xylose, but not from $\mathrm{N}$-acetylglucosamine, D-adonitol, D-arabinose, D- or L-arabitol, arbutin, dulcitol, erythritol, D-fructose, D- or L-fucose, D-galactose, gentiobiose, gluconate, 2-ketogluconate, 5-ketogluconate, glycerol, inositol, inulin, D-lyxose, D-mannose, methyl $\alpha$-D-mannoside, melezitose, L-rhamnose, D-sorbitol, L-sorbose, sucrose, D-tagatose, xylitol, L-xylose or methyl $\beta$-D-xyloside. With
API Rapid ID 32A, positive for raffinose fermentation, $\alpha$ - and $\beta$-galactosidases, $\alpha$ - and $\beta$-glucosidases, arginine arylamidase, glycine arylamidase, histidine arylamidase, leucine arylamidase, phenylalanine arylamidase, proline arylamidase, serine arylamidase and tyrosine arylamidase, but negative for D-mannose fermentation, nitrate reduction, indole production, alkaline phosphatase, arginine dihydrolase, $\beta$-galactosidase- 6 -phosphate, $\alpha$-arabinosidase, $\alpha$ fucosidase, $\beta$-glucuronidase, $N$-acetyl- $\beta$-glucosaminidase, glutamic acid decarboxylase, alanine arylamidase, glutamyl glutamic acid arylamidase, leucyl glycine arylamidase, pyroglutamic acid arylamidase and urease. With API ZYM, positive for acid phosphatase, $\alpha$ - and $\beta$-galactosidases, $\alpha$ - and $\beta$-glucosidases, leucine arylamidase and naphthol-AS-BIphosphohydrolase, but negative for alkaline phosphatase, esterase (C4), esterase lipase (C8), lipase (C14), trypsin, $\alpha$ chymotrypsin, $\alpha$-fucosidase, $N$-acetyl- $\beta$-glucosaminidase, $\beta$-glucuronidase, $\alpha$-mannosidase, cystine arylamidase and valine arylamidase. The $\mathrm{G}+\mathrm{C}$ content of the type strain is $57.8 \mathrm{~mol} \%$.

The type strain, $\mathrm{Eg} 1^{\mathrm{T}}\left(=\mathrm{KCTC} 5756^{\mathrm{T}}=\mathrm{JCM} 15918^{\mathrm{T}}\right)$, was isolated from human faeces.

\section{Acknowledgements}

We thank Dr J. P. Euzéby (Ecole Nationale Vétérinaire, Toulouse, France) for etymological advice. This work was supported in 2009 by the Korea Food \& Drug Administration (grant no. 09172KFDA996).

\section{References}

Baker, G. C., Smith, J. J. \& Cowan, D. A. (2003). Review and re-analysis of domain-specific 16S primers. J Microbiol Methods 55, 541-555.

Biavati, B. \& Mattarelli, P. (1991). Bifidobacterium ruminantium sp. nov. and Bifidobacterium merycicum sp. nov. from the rumens of cattle. Int J Syst Bacteriol 41, 163-168.

Eckburg, P. B., Bik, E. M., Bernstein, C. N., Purdom, E., Dethlefsen, L., Sargent, M., Gill, S. R., Nelson, K. E. \& Relman, D. A. (2005). Diversity of the human intestinal microbial flora. Science 308, 1635-1638.

Ezaki, T., Hashimoto, Y. \& Yabuuchi, E. (1989). Fluorometric deoxyribonucleic acid-deoxyribonucleic acid hybridization in microdilution wells as an alternative to membrane filter hybridization in which radioisotopes are used to determine genetic relatedness among bacterial strains. Int J Syst Bacteriol 39, 224-229.

Gavini, F., Pourcher, A. M., Neut, C., Monget, D., Romond, C., Oger, C. \& Izard, D. (1991). Phenotypic differentiation of bifidobacteria of human and animal origins. Int J Syst Bacteriol 41, 548-557.

Gibson, G. R. \& Roberfroid, M. B. (1995). Dietary modulation of the human colonic microbiota: introducing the concept of prebiotics. J Nutr 125, 1401-1412.

Gonzalez, J. M. \& Saiz-Jimenez, C. (2002). A fluorimetric method for the estimation of $\mathrm{G}+\mathrm{C}$ mol\% content in microorganisms by thermal denaturation temperature. Environ Microbiol 4, 770-773.

Hirayama, H., Tamaoka, J. \& Horikoshi, K. (1996). Improved immobilization of DNA to microwell plates for DNA-DNA hybridization. Nucleic Acids Res 24, 4098-4099.

Jian, W., Zhu, L. \& Dong, X. (2001). New approach to phylogenetic analysis of the genus Bifidobacterium based on partial HSP60 gene sequences. Int J Syst Evol Microbiol 51, 1633-1638. 
Kluge, A. G. \& Farris, J. S. (1969). Quantitative phyletics and the evolution of anurans. Syst Zool 18, 1-32.

Okamoto, M., Benno, Y., Leung, K. P. \& Maeda, N. (2008). Bifidobacterium tsurumiense sp. nov., from hamster dental plaque. Int J Syst Evol Microbiol 58, 144-148.

Orban, J. I. \& Patterson, J. A. (2000). Modification of the phosphoketolase assay for rapid identification of bifidobacteria. J Microbiol Methods 40, 221-224.

Palmer, C., Bik, E. M., DiGiulio, D. B., Relman, D. A. \& Brown, P. O. (2007). Development of the human infant intestinal microbiota. PLoS Biol 5, e177.

Saitou, N. \& Nei, M. (1987). The neighbor-joining method: a new method for reconstructing phylogenetic trees. Mol Biol Evol 4, 406425.

Saulnier, D. M., Spinler, J. K., Gibson, G. R. \& Versalovic, J. (2009). Mechanisms of probiosis and prebiosis: considerations for enhanced functional foods. Curr Opin Biotechnol 20, 135-141.

Scardovi, V. (1986). Genus Bifidobacterium Orla-Jensen 1924, $472^{\mathrm{AL}}$ In Bergey's Manual of Systematic Bacteriology, vol. 2, pp. 1418-1434. Edited by P. H. A. Sneath, N. S. Mair, M. E. Sharpe \& J. G. Holt. Baltimore: Williams \& Wilkins.

Tamura, K., Dudley, J., Nei, M. \& Kumar, S. (2007). MEGA4: molecular evolutionary genetics analysis (MEGA) software version 4.0. Mol Biol Evol 24, 1596-1599.
Thompson, J. D., Gibson, T. J., Plewniak, F., Jeanmougin, F. \& Higgins, D. G. (1997). The CLUSTAL_X windows interface: flexible strategies for multiple sequence alignment aided by quality analysis tools. Nucleic Acids Res 25, 4876-4882.

Turroni, F., Marchesi, J. R., Foroni, E., Gueimonde, M., Shanahan, F., Margolles, A., van Sinderen, D. \& Ventura, M. (2009). Microbiomic analysis of the bifidobacterial population in the human distal gut. ISME J 3, 745-751.

Ventura, M., Canchaya, C., Tauch, A., Chandra, G., Fitzgerald, G. F., Chater, K. F. \& van Sinderen, D. (2007). Genomics of Actinobacteria: tracing the evolutionary history of an ancient phylum. Microbiol Mol Biol Rev 71, 495-548.

Wang, M., Ahrne, S., Jeppsson, B. \& Molin, G. (2005). Comparison of bacterial diversity along the human intestinal tract by direct cloning and sequencing of 16S rRNA genes. FEMS Microbiol Ecol 54, 219-231.

Wayne, L. G., Brenner, D. J., Colwell, R. R., Grimont, P. A. D., Kandler, O., Krichevsky, M. I., Moore, L. H., Moore, W. E. C., Murray, R. G. E. \& other authors (1987). International Committee on Systematic Bacteriology. Report of the ad hoc committee on reconciliation of approaches to bacterial systematics. Int J Syst Bacteriol 37, 463-464.

Zhu, L., Li, W. \& Dong, X. (2003). Species identification of genus Bifidobacterium based on partial HSP60 gene sequences and proposal of Bifidobacterium thermacidophilum subsp. porcinum subsp. nov. Int J Syst Evol Microbiol 53, 1619-1623. 